\title{
Service Quality of Pesantren and Its Impact on the Santri Loyalty
}

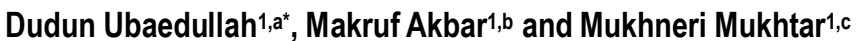 \\ ${ }^{1}$ Department of Education Management, Universitas Negeri Jakarta, Jakarta Timur, 13220, Indonesia \\ a ubaedullah@gmail.com; b makrufakbar@unj.ac.id; c mukhnerimukhtar@unj.ac.id \\ ${ }^{*}$ Corresponding Author
}

How to Cite: Ubaedullah, D. Akbar, M., Mukhtar, M. (2019). Service Quality of Pesantren and Its Impact on the Santri Loyalty. International Journal for Educational and Vocational Studies, 1 (3), 254-260

\section{ARTICLE HISTORY}

Received: 8 June 2019

Revised: 22 July2019

Accepted: 21 July 2019

\section{KEYWORDS}

Pesantren,

Santri Loyalty,

Service Quality of Pesantren

\begin{abstract}
Managing santri loyalty makes pesantren to win competition amid the high growth of pesantren in Indonesia. This study aims to examine santri loyalty model through the image of pesantren, service quality, and santri satisfaction. Samples of this study were 344 students from 2029 students of the largest pesantren in Jakarta and analyzed the data using path analysis. Findings showed that service quality of pesantren has a direct effect on santri loyalty which is the strongest compared to the image of pesantren and santri satisfaction. It is suggested to kyai and managers of pesantren can pay attention to services quality, the image of pesantren, and santri satisfaction, because it is proved to be able to increase santri loyalty. Managing santri loyalty makes pesantren to win competition amid the high growth of pesantren in Indonesia. This study aims to examine santri loyalty model through the image of pesantren, service quality, and santri satisfaction. Samples of this study were 344 students from 2029 students of the largest pesantren in Jakarta and analyzed the data using path analysis. Findings showed that service quality of pesantren has a direct effect on santri loyalty which is the strongest compared to the image of pesantren and santri satisfaction. It is suggested to kyai and managers of pesantren can pay attention to services quality, the image of pesantren, and santri satisfaction, because it is proved to be able to increase santri loyalty.
\end{abstract}

This is an open access article under the CC-BY-SA license.

\section{INTRODUCTION}

As an educational institution in Indonesia, pesantren are faced with competition not only with the pesantren institutions themselves but also with other educational institutions such as madrasas and public schools. In this context, pesantren as a service provider institution need to increase the interest of people to study in pesantren through various strategies, one of which is through the loyalty of santri. Therefore, maintaining and increasing santri loyalty is very important to win the competition.

Santri loyalty can be realized with focuses on the customer so that it can encourage the interest of santri to choose the pesantren and provide positive information to others (word of mouth). Word of mouth intention can also reduce promotional costs because information about pesantren is obtained by word of mouth.

Santri loyalty is also a strategy in the short and long term to increase the competitive advantage with the pesantren or other educational institutions on the basis of three factors. First, getting new santri requires a higher cost than maintaining existing santri. Second, positive word of mouth support from alumni. Third, supporting alumni for pesantren. These three factors were successfully confirmed by Mendez, Parraga, Kara, and Urrutia (2009) in their research in higher education. Researchers have described the factors that impact customer loyalty in the education sector. There are three factors that concern the researcher, namely service quality, organizational image, and customer satisfaction. The issue of customer loyalty is crucial because improving customer loyalty suggests organizational performance. Therefore, this strengthens santri loyalty as customers which in turn will increase the competitiveness of pesantren. Based on this matter, this study examines that findings in pesantren, Indonesian Islamic educational institutions.

\section{LITERATURE}

\subsection{Service Quality of Pesantren}

Pesantren that can provide quality services to stakeholders, especially to santri (internal customers) as people who receive services directly is pesantren that have a competitive advantage. The quality of these 
services is the competitiveness of pesantren to continue to exist and excel from other educational institutions.

As an institution that provides services, the perceptions of santri on pesantren services received are very dependent on the results of the interaction between santri and service providers, including kyai and ustadz. The ability of service providers is one of the characteristics of a service. Therefore, the ability of high service providers shows good service quality.

Furthermore, Brady and Cronin (2003) stated that service quality is a customer evaluation of a service based on the quality of the interaction, the quality of the physical environment, and the quality of the results.

Thus, in this study services quality of pesantren defined as a person's perception about the attitudes and behavior of ustadz, the ability of ustadz, pesantren facilities and pesantren environment.

\subsection{Pesantren Image}

The popularity is one of the reasons for students and parents in choosing pesantren. Pesantren that have been widely known by the public makes it easier for santri or parents to identify these educational institutions. The popularity of pesantren is one form of competitive advantage that can attract the interest of the community towards the pesantren.

In this case, the formation of organizational images can be used by pesantren to influence santri or parents who lack knowledge about the pesantren. This is in line with the opinion of Pampaloni (2010) who stated that "image has greater significance when consumers have had minimal direct experience with an organization". Thus, people who have minimal information about pesantren can be influenced by the image of pesantren advertised through various information media such as websites or social media.

To develop the organization's image can be performed through the development of physical and organizational behavior. Therefore, improving the pesantren image can be built through physical and non-physical attributes such as the popularity, design of pesantren building, pesantren environment, excellent service and customer relations with good educational institutions.

As the identity of the pesantren, the curriculum and programs offered by the pesantren can give a positive impression to the public. The impression of the public on pesantren is also often determined by the alumni. Pesantren alumni who accepted in state universities, alumni who work in well-known companies or institutions, and alumni who become community leaders, for example, can give a positive public impression of pesantren.

Thus, in this study pesantren image defined as a person's perception based on impressions, assumptions, and beliefs of pesantren with indicators: the popularity of pesantren, traditional pesantren, pesantren curriculum, pesantren alumni, and pesantren programs.

\subsection{Santri Satisfaction}

The santri's expectations are derived from their experience from the pesantren or other educational institutions before. However, information received through brochures, websites, word of mouth, or other media can also influence the level of santri expectations which ultimately has implications for the level of satisfaction of pesantren customers.

The level of customer dissatisfaction is generally due to incompatibility between expectations and experiences experienced, poor service acceptance, lack of service provider behavior, environment and facilities that do not support services, high costs, and promotions that do not fit reality.

Customer satisfaction occurs over a while as defined by Tsiotsou (2006) that satisfaction is "an affective summary response from varying intensity of specific time points of determination and limited duration directed toward the aspects of product acquisition and/or consumption. This opinion is supported by Lovelock and Wright (2007) which states that satisfaction is the customer's short-term emotional reaction to the performance of certain services. Emotional reactions indicate that satisfaction or dissatisfaction can occur after post-purchase (post-use) evaluation significantly as customer satisfaction according to Hoffman and Bateson (2010) that a comparison of customer expectation to perceptions regarding the actual service encounter.

Satisfaction is the outcome of the students' understanding which is influenced by pesantren environment. Appropriate Park (2012) states that satisfaction is a "process outcome" that measures students' understanding of the ways in which campus diversity has influenced them.

Measuring the level of customer satisfaction in the university environment was examined by Elliot and Healy (2005) who tested 11 (eleven) indicators of student satisfaction levels, namely (1) effectiveness of academic advice, (2) campus climate, (3) campus life, (4) campus support services, (5) attention to individuals, (6) effectiveness of teaching, (7) effectiveness of recruitment and financial assistance, (8) effectiveness of registration, (9) campus safety and security, (10) service excellence, and (11) student centering. From these indicators, only three indicators are supposed to measure the level of student satisfaction, namely student centering, campus climate, and teaching effectiveness.

For this study, santri satisfaction defined as the emotional level of santri in the form of pleasure, pride, and happiness towards the learning experience in 
pesantren with indicators: academic facilities, non-academic facilities, talent development support, ustadz guidance, and santri centeredness.

\subsection{Santri Loyalty}

Supporting customer in an educational institution is one of the benefits for educational institutions, especially private education institutions, including pesantren. Therefore, pesantren always attempt to maintain santri until they complete their study at the pesantren or maintain them to continue into the same educational institution as further studies if they have various levels of education. Choosing pesantren for further study in the same education institution can be stated as a repurchase behavior.

Customer loyalty is not only perceived as repurchasing behavior but also is a loyalty of customers to repurchase a product or service. Kotler and Keller (2016) defined customer loyalty is "a commitment to rebuy or re-patronize a preferred product or service".

Repeated purchases at educational institutions can be interpreted as two forms. First, for pesantren that have more than one of education level, repeat purchases can be interpreted as a willingness of students to continue at the next level of education in the same pesantren. Secondly, it can be interpreted as the willingness of students to complete their studies when pesantren do not have a higher level of education. Therefore, Mohamad and Awang (2009) defined customer loyalty to university education as "willingness to remain at the university to complete their existing undergraduate programs and their intention to study at the same university again in the future".

Kunanusorn and Puttawong (2015) stated "student loyalty is the combination between student willingness to provide positive words of mouth about the institution and recommendation concerning educational institution to family, friends, employers, and organizations whenever opportunities are". A similar statement was expressed by Athiyaman in Alves and Raposo (2007) who stated "loyalty is the combination between students willingness to talk positively about the institution and to provide information to new candidates".

Based on the description above explains that santri loyalty contains three elements. First, there is loyalty to using education services in the same pesantren. Second, give positive recommendations to others as a choice of study in the pesantren. Third, there is "immunity" of santri to not move to other pesantren or other educational institutions.

Thus, santri loyalty defined as the commitment of santri to use education services on continuing support and recommend it to others with indicators positive attitudes towards pesantren, choosing the same pesantren as a place of further study, providing positive recommendations to other people, and rejecting offers from other educational institutions.

\section{HYPOTHESIS DEVELOPMENT}

\section{Service Quality}

Many researchers have confirmed that service quality has a positive impact on the organizational image. According to Aydin and Ozer (2005), the organization's image derived from consumer experience in using services and service quality is a function of that experience while Nguyen and LeBlanc (1998) claim that customers who receive a higher level of service quality during service delivery will improve the organization's image. The similar situation also found the influence of service quality on the image of the Institute at the university level.

Service quality also has a positive impact on an organizational image in Educational Institutions. It is important to fulfill students learning responsibilities within attitudes, behavior, and ability of service providers in educational institutions. This is in line with the theory of Brady and Cronin (2003) which states that through attitudes, behaviors, and abilities service providers can measure the level of customer satisfaction. On the other hand, physical facilities on campus also play a major role in satisfying students. Sultan and Wong (2013) suggested that service quality and satisfaction are attitude driven. While perceived quality is a long run overall evaluation, satisfaction is the outcome of the overall evaluation.

The results of Helgesen and Nesset (2007) conducted on a number of Aalesund University College (AAUC) students in Norway showed that service quality and customer satisfaction had a positive influence on the loyalty of Aalesund University College (AAUC) students. In addition, Helgesen and Nesset (2007) also succeeded in proving the influence of the study program image and university image on student loyalty.

Based on these explanations the hypothesis in this study can be stated as follows:

H1: Service quality of pesantren has positive impact on pesantren image.

H2: Service quality of pesantren has positive impact on santri satisfaction.

\section{Organizational Image}

The image formed by an organization can be communicated with stakeholders so that it can be known and understood so that perception and impression are formed in the external mind of the organization. Therefore, pesantren can make efforts to improve the image of pesantren through tradition, ideology, diversity of services and the quality of 
communication from the people involved in the organization.

Thus, improving the perception of santri towards the service quality of pesantren can increase santri satisfaction. Based on these explanations the hypothesis in this study can be stated as follows:

H3: Pesantren image has positive impact on santri satisfaction.

\section{Santri Loyalty}

Santri loyalty is santri behavior in which always use the educational services offered, will be satisfied and continue to use educational services when pesantren can provide good quality services.

Improving customer loyalty in education was determined by service quality, organizational image, and perceived value. Meanwhile, Annamdevula and Bellamkonda (2016) have also proven that student loyalty influenced by the quality of service through student satisfaction as a mediator.

Based on these explanations the hypothesis in this study can be stated as follows:

H4: Service quality of pesantren has positive impact on santri loyalty.

H5: Pesantren image has positive impact on santri loyalty.

H6: Santri satisfaction has positive impact on santri loyalty.

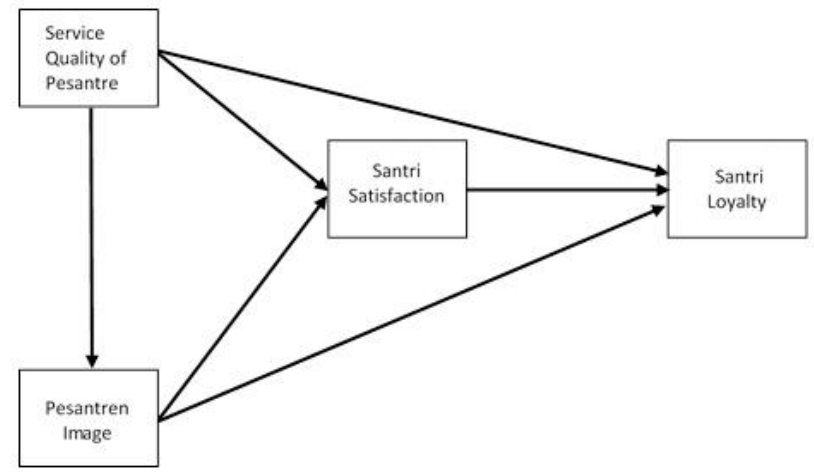

Figure 1. Conceptual Framework

\section{METHODOLOGY}

This study was conducted at a well-known pesantren in Jakarta during 2017 academic year with a total population of 2029 students. The population of this study was all students who lived in pesantren for at least one year to avoid the homesick situation that can influence the measurement of santri satisfaction.

This study included a survey by questionnaire were designed using a 5-point Likert Scale and distributed to 344 santris using the simple random sampling technique.

This study used a quantitative approach and path analysis to test the hypothesis. Lisrel 9.30 student used to analyze a path diagram. Besides, SPSS 25 used to measure validity and reliability. Alpha Cronbach is used for reliability testing.

\section{FINDING AND DISCUSSION}

The following table illustrates how the level of correlation between the variables studied.

Table 1. correlation between variables

\begin{tabular}{|c|c|c|c|c|c|}
\hline \multicolumn{6}{|c|}{ Correlations } \\
\hline & & $\begin{array}{l}\text { Service } \\
\text { Quality of } \\
\text { Pesantren }\end{array}$ & $\begin{array}{l}\text { Pesantren } \\
\text { Image }\end{array}$ & $\begin{array}{c}\text { Santri } \\
\text { Satisfaction }\end{array}$ & $\begin{array}{l}\text { Santri } \\
\text { Loyalty }\end{array}$ \\
\hline \multirow{3}{*}{$\begin{array}{l}\text { Service } \\
\text { Quality of } \\
\text { Pesantren }\end{array}$} & Pearson Correlation & 1 & $.619^{\star x}$ & $.683^{* \pi}$ & $.472^{\mathrm{n}}$ \\
\hline & Sig. (2-tailed) & & .000 & .000 & .000 \\
\hline & $\mathrm{N}$ & 344 & 344 & 344 & 344 \\
\hline \multirow{3}{*}{$\begin{array}{l}\text { Pesantren } \\
\text { Image }\end{array}$} & Pearson Correlation & $.619^{* \prime}$ & 1 & $.659^{* *}$ & $.469^{n *}$ \\
\hline & Sig. (2-tailed) & .000 & & .000 & .000 \\
\hline & $\mathrm{N}$ & 344 & 344 & 344 & 344 \\
\hline \multirow{3}{*}{$\begin{array}{l}\text { Santri } \\
\text { Satisfaction }\end{array}$} & Pearson Correlation & $.683^{\mathrm{N}}$ & $.659^{\prime \prime}$ & 1 & $.452^{\mathrm{k}}$ \\
\hline & Sig. (2-tailed) & .000 & .000 & & .000 \\
\hline & $\mathrm{N}$ & 344 & 344 & 344 & 344 \\
\hline \multirow{3}{*}{$\begin{array}{l}\text { Santri } \\
\text { Loyalty }\end{array}$} & Pearson Correlation & $.472^{\kappa *}$ & $.469^{* *}$ & $.452^{\mathrm{**}}$ & 1 \\
\hline & Sig. (2-tailed) & .000 & .000 & .000 & \\
\hline & $\mathrm{N}$ & 344 & 344 & 344 & 344 \\
\hline
\end{tabular}

Table 1 showed that the correlation in this study is significant and meets the requirements for the regression test. Then a regression test was carried out based on the hypothesis of this study.

H1: Service quality of pesantren towards pesantren image

Table 2. Path Coefficients of substructure 1

\begin{tabular}{|c|c|c|c|c|c|c|}
\hline \multicolumn{7}{|c|}{ Coefficients $^{\mathrm{a}}$} \\
\hline \multirow[b]{2}{*}{ Model } & & \multicolumn{2}{|c|}{ Unstandardized Coefficients } & \multirow{2}{*}{$\begin{array}{c}\text { Standardized } \\
\text { Coefficients } \\
\text { Beta }\end{array}$} & \multirow[b]{2}{*}{$\mathrm{t}$} & \multirow[b]{2}{*}{ Sig. } \\
\hline & & $\mathrm{B}$ & Std. Error & & & \\
\hline \multirow[t]{2}{*}{1} & (Constant) & 56.974 & 5.133 & & 11.099 & .000 \\
\hline & $\begin{array}{l}\text { Service Quality of } \\
\text { Pesantren }\end{array}$ & .537 & .037 & .619 & 14.564 & .000 \\
\hline
\end{tabular}

Table 2 showed that path coefficient $\left(\rho_{21}\right)$ service quality of pesantren towards pesantren image is 0.619 and $t_{\text {value }}$ is 14.564 . So, service quality of pesantren has direct positive effect on pesantren image and service quality of pesantren contributed $38.32 \%$ to pesantren images.

According to Nguyen and Leblanc (2001), "tangible elements, such as contact personnel and physical environment, might be used given their effect on corporate image". Based on the analysis it is found that service quality of pesantren has direct positive effects on pesantren image.

H2: Service quality of pesantren towards santri satisfaction 
Table 3. Path Coefficients of substructure 2

\begin{tabular}{|c|c|c|c|c|c|c|}
\hline \multicolumn{7}{|c|}{ Coefficients $^{a}$} \\
\hline \multirow[b]{2}{*}{ Model } & & \multicolumn{2}{|c|}{ Unstandardized Coefficients } & \multirow{2}{*}{$\begin{array}{c}\text { Standardized } \\
\text { Coefficients } \\
\text { Beta }\end{array}$} & \multirow[b]{2}{*}{$\mathrm{t}$} & \multirow[b]{2}{*}{ Sig. } \\
\hline & & B & Std. Error & & & \\
\hline \multirow[t]{3}{*}{1} & (Constant) & 4.744 & 6.415 & & .740 & .460 \\
\hline & $\begin{array}{l}\text { Service Quality of } \\
\text { Pesantren }\end{array}$ & .488 & .050 & .445 & 9.708 & .000 \\
\hline & Pesantren Image & .485 & .058 & 384 & 8.365 & .000 \\
\hline
\end{tabular}

Table 3 showed that path coefficient $\left(\rho_{31}\right)$ service quality of pesantren towards santri satisfaction is 0.445 and $t_{\text {value }}$ is 9.708. So, service quality of pesantren has direct positive effect on santri satisfaction and service quality of pesantren contributes $19.80 \%$ to santri satisfaction.

According to Brady and Cronin (2003) that attitude, behavior, and ability of service providers can measure the level of customer satisfaction. Based on the analysis it is found that service quality of pesantren has direct positive effects on santri satisfaction.

H3: Pesantren image towards on santri satisfaction

Table 3 showed that path coefficient ( $\left.\rho_{32}\right)$ pesantren image towards santri satisfaction is 0.384 and $t_{\text {value }}$ is 8.365. So, pesantren image has direct positive effect on santri satisfaction and pesantren image contributes $14,75 \%$ to santri satisfaction.

According to Leonnard (2017) that positive image of higher education institution will increase student satisfaction. Based on the analysis it is found that pesantren image has direct positive effects on santri satisfaction.

H4: Service quality of pesantren towards on santri loyalty

Table 4. Path Coefficients of substructure 3

\begin{tabular}{|c|c|c|c|c|c|c|}
\hline \multicolumn{7}{|c|}{ Coefficients $^{a}$} \\
\hline \multirow[b]{2}{*}{ Model } & & \multicolumn{2}{|c|}{ Unstandardized Coefficients } & \multirow{2}{*}{$\begin{array}{l}\text { Standardized } \\
\text { Coefficients } \\
\text { Beta }\end{array}$} & \multirow[b]{2}{*}{$t$} & \multirow[b]{2}{*}{ Sig. } \\
\hline & & B & Std. Error & & & \\
\hline \multirow[t]{4}{*}{1} & (Constant) & 22.143 & 8.532 & & 2.595 & .010 \\
\hline & $\begin{array}{l}\text { Service Quality of } \\
\text { Pesantren }\end{array}$ & .266 & .075 & .233 & 3.524 & .000 \\
\hline & Pesantren Image & .306 & .085 & .232 & 3.620 & .000 \\
\hline & Santri Satisfaction & .146 & .072 & .140 & 2.027 & .043 \\
\hline
\end{tabular}

Table 4 showed that path coefficient $\left(\rho_{y 1}\right)$ service quality of pesantren towards santri loyalty is 0.233 and $t_{\text {value }}$ is 3.524 . So, service quality of pesantren has direct positive effect on santri loyalty.

According to Mansori, Vaz, and Ismail (2014) that tangibility has the highest influence on the students' intention to continue to a higher level of studies and/or spreading good word of mouth about the institution to their friends and the society. Based on the analysis it is found that pesantren image has direct positive effects on santri satisfaction.

\section{H5: Pesantren image towards on santri loyalty}

Table 4 showed that path coefficient $\left(\rho_{\mathrm{y} 2}\right)$ pesantren image towards santri loyalty is 0.232 and $t_{\text {value }}$ is 3.620 . So, pesantren image has direct positive effect on santri loyalty and pesantren image contributes $5.38 \%$ to santri loyalty.

According to Jiewanto, Laurens and Nelloh that when the students got positive image toward the university, they will tend give positive recommendations or spread positive word of mouth. Based on the analysis it is found that pesantren image has direct positive effect on santri loyalty.

H6: Santri satisfaction has significant eff ect on santri loyalty

Table 4 showed that path coefficient $\left(\rho_{\mathrm{y} 3}\right)$ santri satisfaction towards santri loyalty is 0.140 and $t_{\text {value }}$ is 2.027. So, santri satisfaction has direct positive effect on santri loyalty and pesantren image contributes $1.96 \%$ to santri loyalty.

This study support consistently similar to the findings of experts in marketing education services as founded by Kunanusorn \& Puttawong (2015); Leonnard et al. (2017); Mohamad and Awang (2009); Sharif and Kassim (2012). Based on the analysis it is found that santri satisfaction has direct positive effect on santri loyalty

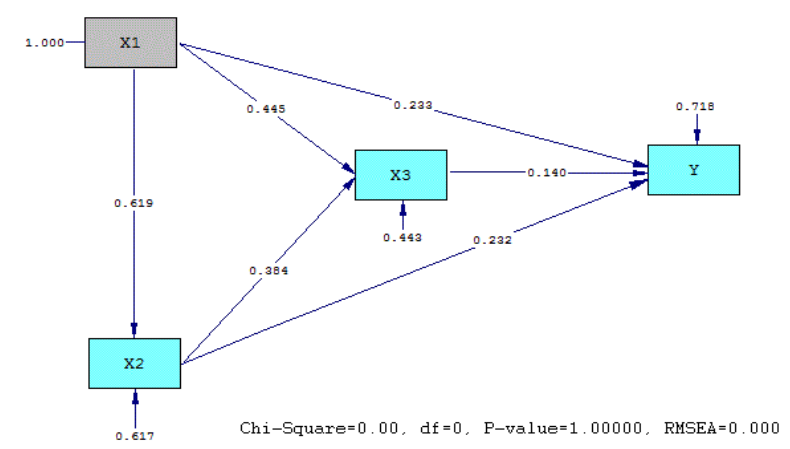

Figure 2. path coefficients

\section{CONCLUSION}

The finding of this study concludes that service quality of pesantren has positive effect on pesantren Image, Service quality of pesantren has positive effect on santri satisfaction, pesantren image has positive effect on santri Satisfaction, service quality of pesantren has positive effect on Santri Loyalty, pesantren image has positive effect on Santri Loyalty, santri satisfaction has significant effect on Santri Loyalty.

This study also concludes that service quality of pesantren contributes the most significant impact, with regards to the level of santri loyalty.

Furthermore, this study suggests that pesantren can increase santri loyalty through improving quality services of pesantren such as making dormitory with an attractive exterior and interior design, increasing the ability of ustadz to guide students so that they get a better learning experience. 


\section{LIMITATIONS}

This study only tested three variables to examine santri loyalty. So, there are still many variables that need to be tested to determine the level of influence on santri loyalty.

Also, this research was conducted in modern pesantren (khalafi). The results can be different if the research is conducted in traditional pesantren (salafi).

\section{REFERENCES}

Abdullah, F. (2006). Measuring service quality in higher education: Three instruments compared. International Journal of Research and Method in Education.

https://doi.org/10.1080/01406720500537445

Alves, H., \& Raposo, M. (2007). The Influence of University Image in Student'S Expectations, Satisfaction and Loyalty. In 29th Annual European Higher Education Society (EAIR) Forum.

Annamdevula, S., \& Bellamkonda, R. S. (2016). The effects of service quality on student loyalty: the mediating role of student satisfaction. Journal of Modelling in Management. https://doi.org/10.1108/JM2-04-2014-0031

Ashraf, S., Ilyas, R., Imtiaz, M., \& Ahmad, S. (2018). Impact of Service Quality, Corporate Image and Perceived Value on Brand Loyalty with Presence and Absence of Customer Satisfaction: A Study of four Service Sectors of Pakistan. International Journal of Academic Research in Business and Social Sciences. https://doi.org/10.6007/ijarbss/v8-i2/3885

Aydin, S., \& Özer, G. (2005). The analysis of antecedents of customer loyalty in the Turkish mobile telecommunication market. European Journal of Marketing.

https://doi.org/10.1108/03090560510601833

Brady, M. K., \& Cronin, J. J. (2003). Some New Thoughts on Conceptualizing Perceived Service Quality: A Hierarchical Approach. Journal of Marketing. https://doi.org/10.1509/jmkg.65.3.34.18334

Elliott, K. M., \& Healy, M. A. (2005). Key Factors Influencing Student Satisfaction Related to Recruitment and Retention. Journal of Marketing for Higher Education.

https://doi.org/10.1300/j050v10n04_01

Helgesen, Ø., \& Nesset, E. (2007). Images, Satisfaction and Antecedents: Drivers of Student Loyalty? A Case Study of a Norwegian University College. Corporate Reputation Review.

https://doi.org/10.1057/palgrave.crr.1550037
Hoffman, K. D., \& Bateson, J. E. G. (2010). Services Marketing: Concepts, Strategies, \& Cases. Learning.

Jiewanto, A., Laurens, C., \& Nelloh, L. (2012). Influence of Service Quality, University Image, and Student Satisfaction toward WOM Intention: A Case Study on Universitas Pelita Harapan Surabaya. Procedia Social and Behavioral Sciences.

https://doi.org/10.1016/j.sbspro.2012.03.155

Kotler, P., \& Armstrong, G. (2012). Principles of marketing (14th ed.). New Jersey: Prentice Hall.

Kunanusorn, A., \& Puttawong, D. (2015). The Mediating Effect of Satisfaction on Student Loyalty to Higher Education Institution. European Scientific Journal, ESJ.

Lovelock, C. (2001). Service Marketing: People, Techonoligy, Strategy (4th ed.). USA: Prentice Hall.

Mansori, S., Vaz, A., \& Ismail, Z. M. M. (2014). Service quality, satisfaction and student loyalty in Malaysian private education. Asian Social Science, 10(7), 57-66. https://doi.org/10.5539/ass.v10n7p57

Mohamad, M., \& Awang, Z. (2009). Building Corporate Image and Securing Student Loyalty in the Malaysian Higher Learning Industry. The Journal of International Management Studies.

Nguyen, N, \& LeBlanc, G. (1998). The Mediating role or corporate on customers retentions decisopms: an invertigation in financial services. International Journal of Bank Marketing, 16(2), 52-65. https://doi.org/10.1108/02652329810206707

Nguyen, Nha, \& Leblanc, G. (2001). Corporate image and corporate reputation in customers' retention decisions in services. Journal of Retailing and Consumer Services, 8(4), 227-236. https://doi.org/10.1016/S0969-6989(00)00029-1

Pampaloni, A. M. (2010). The influence of organizational image on college selection: What students seek in institutions of higher education. Journal of Marketing for Higher Education, 20(1), 19-48. https://doi.org/10.1080/08841241003788037

Park, J. J. (2012). Are We Satisfied?: A Look at Student Satisfaction with Diversity at Traditionally White Institutions. The Review of Higher Education. https://doi.org/10.1353/rhe.0.0071

Philip Kotler, \& Kevin Lane Keller. (2016). Marketing Management (15th ed.). New York: Pearson.

Rojas-Méndez, J., Vasquez-Parraga, A. Z., Kara, A., \& Cerda-Urrutia, A. (2009). Determinants of student loyalty in higher education: A tested relationship approach in latin America. Latin American Business Review. https://doi.org/10.1080/10978520903022089 
Sultan, P., \& Wong, H. Y. (2013). Antecedents and consequences of service quality in a higher education context. Quality Assurance in Education, 21(1), 70-95. https://doi.org/10.1108/09684881311293070

Tsiotsou, R. (2006). The role of perceived product quality and overall satisfaction on purchase intentions. International Journal of Consumer Studies. https://doi.org/10.1111/j.1470-6431.2005.00477.x

Wilkins, S., \& Huisman, J. (2013). Student Evaluation of University Image Attractiveness and Its Impact on Student Attachment to International Branch Campuses. Journal of Studies in International Education.

https://doi.org/10.1177/1028315312472984 